\title{
IIASA appoints US director in hopes of attracting US funds
}

\section{Laxenberg, Austria}

HOPEFUL of a reinstatement of financial support from the United States, the council of the International Institute for Applied Systems Analysis (IIASA) has once again selected a US director, Robert Henry Pry, for the three years ahead. Pry was appointed at a meeting on 12 June by the IIASA governing council, which also appointed Vladimir Sergeevich Mikhalevich of the Soviet Union as chairman.

Pry is a former adjunct professor in materials science at the Massachusetts Institute of Technology (MIT) who is now a private management consultant. By appointing another US director, IIASA keeps links with the United States in spite of a National Security Council decision in March to block a $\$ 500,000$ grant from the US National Science Foundation (NSF) to the institute.

IIASA, a joint think-tank established in 1972 at Laxenberg, near Vienna, by the United States and the Soviet Union as well as ten other countries, has had a US director and a Soviet chairman since its inception. The institute brings in scientists from all the member countries, which now number sixteen, to study global problems such as forest decline, river management and world hunger. US funds were withdrawn in 1982 following a spy scandal and charges that IASA was leaking US technology to the Soviets. The NSF grant was the first attempt to restore US funding to IIASA since that time.

New chairman Mikhalevich, a mathematician specializing in systems analysis, is director of the 7,000-member Glushkov Institute of Cybernetics of the Ukranian
Academy of Sciences. He is also a member of the Supreme Soviet.

The reasons for the US withdrawal of funds from IIASA were "not even political" at first, said outgoing director Lee. A victim of the 1981 Reagan budget cut, the $\$ 2.3$ million annual dues were reinstated later that year by Congress. But in 1982, the Reagan administration found "all kinds of reasons" to stop supporting IIASA. For instance, a Vax computer that had been installed in the 1970 s was considered a technology leak to the Soviet Union. Although the deal was supported at the time by US politicians, buying a Vax was a "mistake", said IIASA secretary Jean-Pierre Ayrault.

Despite the conclusion of two National Academy of Sciences committees that there was no security problem at IIASA, US support was eliminated in 1982. Lee traces the cause to "a small group of powerful people" at the Department of Defense and elsewhere who believe that "any time you have something to do with the Russians you always lose". The 1987 National Security Council decision to block the NSF grant came despite approval of the grant by the US State Department.

Amid the political turmoil of the past five years, IIASA has shifted its focus to more application-orientated projects to try to attract external support. After 15 years, IIASA is seen to be entering a new phase in which it needs to justify itself scientifically. The choice of Pry as director reflects the hope that US policy towards IIASA may change in 1988.

Steven Dickman

\section{Shake-up of UK junior ministers}

\section{London}

IN a wide-ranging ministerial shake-up announced last week by the new Conservative government, the number of ministers in the Department of Education and Science (DES) increased from four to five, while at the Department of Trade and Industry (DTI), the title of Minister for Information Technology was dispensed with. The increased size of the ministerial team at DES is seen as a way to ensure a smooth passage of the Education Bill, which will introduce a major restructuring of higher and lower education. Mr George Walden, the former higher education minister who retired for personal reasons, is replaced by Mr Robert Jackson, who will continue Walden's review of student support, expected to be completed by the end of the year, and will preside over the finalization of the proposed system of con- tract funding in universities and polytechnics. Baroness Hooper will take responsibility for the city technology colleges.

At DTI, the sacking of Mr Geoffrey Pattie, knighted in the Queen's Birthday Honours list, gives increased responsibility to his former number two, Mr John Butcher, who will take over DTI's research and development programme. Mr Kenneth Clarke, deputy to the new Secretary of State, Lord Young, will assume responsibility for European Community research and development. At the Department of the Environment, Mr William Waldegrave relinquishes the environmental portfolio to Lord Belstead, former Minister of State at the Ministry of Agriculture. Mr Michael Jopling, sacked Minister of Agriculture, is replaced by Mr John MacGregor, former Chief Secretary to the Treasury.

Simon Hadlington

\section{A helping hand for inventors}

\section{London}

A NOVEL scheme to minimize red tape and to help British inventors to exploit commercially the fruits of their research has been launched by a UK finance house in partnership with a US research group.

The British arm, called 3i (Investors in Industry), which claims to have provided finance and managerial support to dozens of start-up companies and currently has more than 60 investments in the United Kingdom and the United States, has joined forces with Research Corporation of Tucson, Arizona, to run the scheme. The British group has already created six companies spawned directly from university research while the US group claims to specialize "in converting academic inventions into commercially viable innovation and in technology transfer"

The new scheme, called 'Enterprise Cheques', will provide seed money for the development of "significant inventions and technological advances" of up to $£ 25,000$ for each project, in return for a stake in the technology being developed.

The programme, say the backers, is intended to appeal in particular to those in universities and research establishments but is also available to researchers conducting their own private work. All areas of interest in science and technology will be considered for the scheme which expects to issue about 15 cheques a year.

Managerial expertise is also to be made available to inventors when their projects reach the final stages of development. A new company will be created to exploit the respective technology or a licensing agreement devised so that others can exploit the development, whatever "is considered the best way forward".

According to $3 \mathrm{i}$ : "The UK is still a world leader when it comes to invention and the development of new technologies and ideas ... We have designed the scheme to be as unbureaucratic and simple as possible".

Bill Johnstone

- University researchers were last year encouraged by the government to exploit their own inventions - rather than channel them through the bureaucracy of the British Technology Group (BTG). But ironically the BTG last week scored a major triumph in the defence of British patents and realized substantial royalties for the British inventors of advanced medical scanners. The US electrical conglomerate General Electric is to pay BTG an undisclosed sum, believed to be millions of dollars, in royalties accruing from the sale of scanners in the past two years. Among the beneficiaries will be teams from Nottingham and Aberdeen universities. 